\title{
Laboratory Model Tests on Consolidation Performance of Soil Column with Drained-Timber Rod
}

\author{
X. J. Chai, K. Deng ${ }^{(D,}$, C. F. He, and Y. F. Xiong \\ School of Civil \& Architecture Engineering, East China University of Technology, Nanchang, Jiangxi, China \\ Correspondence should be addressed to K. Deng; 201810818023@ecut.edu.cn
}

Received 12 October 2020; Revised 18 February 2021; Accepted 13 March 2021; Published 22 March 2021

Academic Editor: Francisco Taveira Pinto

Copyright (c) $2021 \mathrm{X}$. J. Chai et al. This is an open access article distributed under the Creative Commons Attribution License, which permits unrestricted use, distribution, and reproduction in any medium, provided the original work is properly cited.

\begin{abstract}
Timber pile is an ancient technology applied in soft ground improvement for more than 1000 years. With the rise of many highrise buildings, many types of modern mechanized-construction piles are widely developed and applied; for example, steel pile, precast concrete pile, sand pile, and gravel pile are widely used instead of timber piles. Yet, in some special conditions, timber piles have certain advantages due to their environment-friendly characteristics, which result in obvious economic benefits and suitability. To overcome the weakness of the traditional timber pile technology and expand its application in engineering practice, a drained-timber pile technique was put forward. This technology is to wrap the permeable filter-type drainage geotextile around the timber pile, so that the timber pile not only has the replacement function to strengthen the foundation but also has the drainage function, can accelerate the pore water discharge, and speeds up the soft soil foundation consolidation. The reduced scale soilcolumn consolidation model was designed to perform the consolidation tests for the soil column with a drained-timber rod. In total, eight types of soil-column consolidation tests were carried out to verify the feasibility and effectiveness of the drained-timber pile technique. The results revealed that, under the same loading and consolidation time, the drained-timber rod can obviously increase the degree of consolidation when compared with traditional timber rod. It can be expected that the drained-timber pile technique has a good application prospect for the construction of medium-small hydraulic structures and for the treatment of super soft clay.
\end{abstract}

\section{Introduction}

Pine pile is an ancient technology applied in soft ground improvement for more than 1000 years. For example, even after more than one thousand years, wood reinforcement under the Mizuki embankment in North Kyushu, Japan, still has high durability in an underwater-table condition [1]. The soft clay foundation of the ancient Water-Gate site of the Southern Taizhou (Jiangsu Province, China) that was reinforced with timber piles still remains in a relatively complete state more than one thousand years at underground water condition [2]. Many ancient ruins were excavated and it was found that the pine piles were still in good status, showing that the pine piles have good durability and strong corrosion resistance under water condition.

Since the 1980s, with the rise of many high-rise buildings, steel piles, precast concrete piles, sand piles, gravel piles, and other modern mechanized-construction pile types were developed and applied in order to meet the requirements of the modern buildings for the bearing capacity and the foundation settlement. Especially, for large soft foundation area, preloading and vacuum preloading techniques have been widely employed to improve the engineering properties of the soft clay [3-6].

However, it cannot be concluded that the timber pile technique has disappeared in soft ground improvements. On the contrary, in some special conditions, timber piles have certain advantages when compared with concrete piles, steel piles, and so forth. For example, timber piles are widely employed in small-medium size hydraulic engineering structures in regions with rich pine resources [7-9]. In recent years, with the enhancement of environmental protection and resource protection conscious, the timber pile technique has been attracting the attention of engineers and 
researchers due to its environment-friendly characteristics, which results in obvious economic benefits and suitability. Yang et al. [10] analyzed and designed a timber pile composite foundation for the Qinhuai River sewage project (Nanjing, China) which was built on very soft clay. Poungchompu et al. [11, 12] investigated the effectiveness and possibility of timber raft and pile foundation for road embankment built on Ariake soft clay (Kyushu, Japan) through laboratory model tests.

However, the traditional timber pile technique has the following two disadvantages when applied to improve the soft ground: (1) the low bearing capacity of the timber pile and the low shear strength of the soft clay restrict the height of the superstructures and (2) the large postconstruction settlement due to the low permeability of the soft clay frequently leads to cracking of the superstructures. The above two problems restrict the extensive application of timber pile composite foundation for buildings in soft soil area.

To overcome the weakness of the traditional timber pile technology, the drained-timber pile technique was developed $[13,14]$. The main feature of the drained-timber pile technique is that a thin layer of drained-geotextile was wrapped around the timber pile, so that the excess pore water will be drained through the geotextile layer during construction; thus, the bearing capacity of the timber pile will be increased and the postconstruction settlement will be reduced.

In the study, to verify the drainage feasibility and efficiency of the drained-timber pile technique, a special laboratory soil-column apparatus was designed to perform consolidation tests for drained-timber rods. In total, eight types of soil-column consolidation tests were carried out to investigate the influence of drainage conditions, the number of layers of drained geotextiles, and the diameter of timber rod. The test results revealed that, under the same loading and consolidation conditions, the drained-timber rod can obviously increase the degree of consolidation when compared with the traditional timber rod. The final outer diameter of the drained-timber rod has a significant impact on the consolidation degree. It can be expected that the drainedtimber pile technique has a good application prospect for the medium-small hydraulic structures and pretreatment of super soft foundation in pine-rich areas.

\section{Experimental Setup}

2.1. Soil Preparation. The soil tested was collected from Diezi Lake of Nanchang city, Jiangxi Province. It is a typical mucky clay in the Poyang Lake region. After being mixed, the soil samples were sealed in a container to maintain the initial condition for tests, as shown in Figure 1. The main physical properties of the soil are listed in Table 1.

2.2. Drainage Geotextile. The drainage geotextile is the main composition of the drained-timber pile, a nonwoven geotextile, which is made of $150 \mathrm{~A}$ with a density of $150 \mathrm{~g} / \mathrm{cm}^{3}$ and a thickness of $1.0 \mathrm{~mm}$. It was employed as the drained

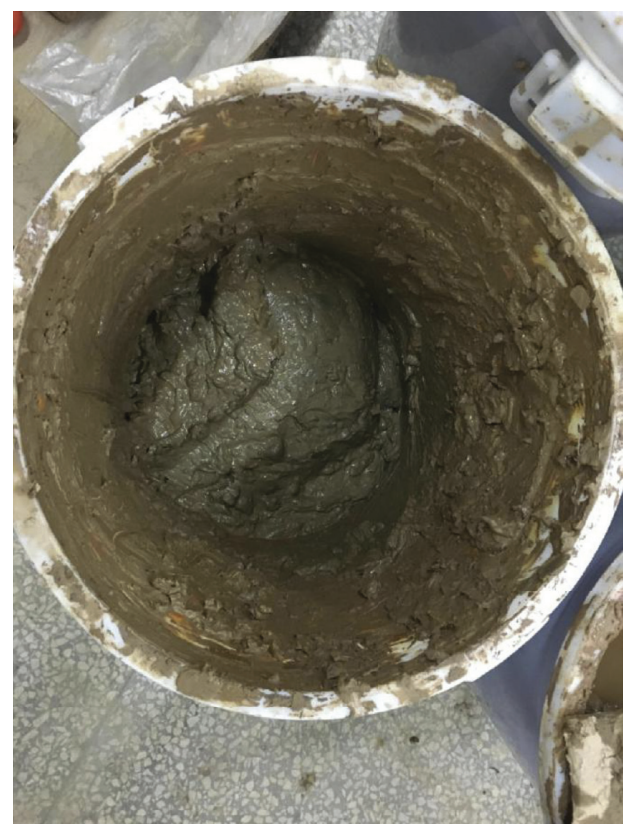

Figure 1: Soil slurry at initial condition.

layer of the drained-timber rod. The permeability coefficient of the geotextile is about $0.1 \mathrm{~cm} / \mathrm{s}$, and its tensile strength is greater than $0.12 \mathrm{kN}$.

\subsection{Preparation of Timber Rod and Drained-Timber Rod.} The diameter of the pine pile commonly used in engineering practices is between $100 \mathrm{~mm}$ and $150 \mathrm{~mm}$. In the experiments, the dimension of the soil-column consolidation test apparatus was scaled down in a ratio of one to ten. Therefore, three different sizes of timber rods with diameters of $8 \mathrm{~mm}$, $10 \mathrm{~mm}$, and $12 \mathrm{~mm}$ and length of $100 \mathrm{~mm}$ were made in this study. The elastic modulus of the timber $\operatorname{rod} f_{\mathrm{c}}=10 \mathrm{MPa}$, $E f_{\mathrm{c}}=9000 \mathrm{MPa}$, and $11 \mathrm{MPa}$ of bending resistance. On the basis of the research group, the number and thickness of the wrapped geotextile have little effect on the drainage effect, so the standard geotextile used in engineering is selected in this test, and the thickness is not reduced. The compressive strength of the pine rod is $f_{\mathrm{c}}=12 \mathrm{MPa}$.

The drained-timber rod is made up of a timber rod with a few layers of drainage geotextile wrapped around the timber rod. Photos of the timber rod and the drained-timber rod for the wooden rod with a diameter of $10 \mathrm{~mm}$ are shown in Figure 2.

\subsection{Laboratory Soil-Column Consolidation Test Setup.} The laboratory soil-column consolidation test apparatus was composed of a plexiglass cylinder, a pressure plate, a plexiglass hollow transfer column, a loading, and a data monitoring-recording system.

The plexiglass cylinder was made of plexiglass with a thickness of $5 \mathrm{~mm}$, an inner diameter of $100 \mathrm{~mm}$, and a height of $150 \mathrm{~mm}$, an impervious bottom and side of the cylinder, as shown in Figure 3(a). 
TABle 1: Physical properties of the mucky clay used in the test.

\begin{tabular}{|c|c|c|c|c|c|c|}
\hline $\begin{array}{l}\text { Natural density, } \\
\rho\left(\mathrm{g} / \mathrm{cm}^{3}\right)\end{array}$ & Water content, $\omega(\%)$ & Specific gravity, $G_{s}$ & Plastic limit (PL) & Liquid limit (LL) & Plasticity index (PI) & $\begin{array}{l}\text { Liquidity } \\
\text { index (LI) }\end{array}$ \\
\hline 1.74 & 90.26 & 2.67 & 26.0 & 52.2 & 26 & 2.47 \\
\hline
\end{tabular}

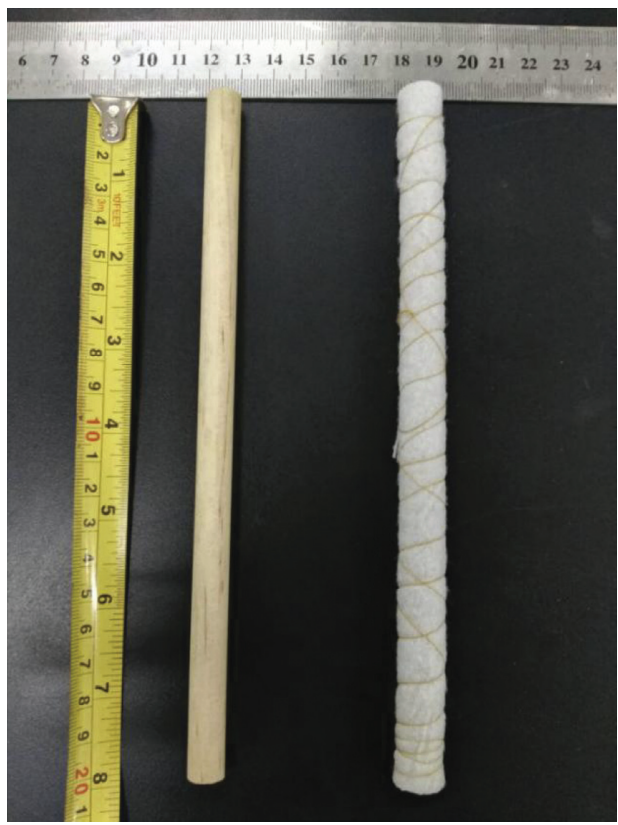

Figure 2: Photos of timber rod and drained-timber rod for a wooden rod with a diameter of $10 \mathrm{~mm}$.

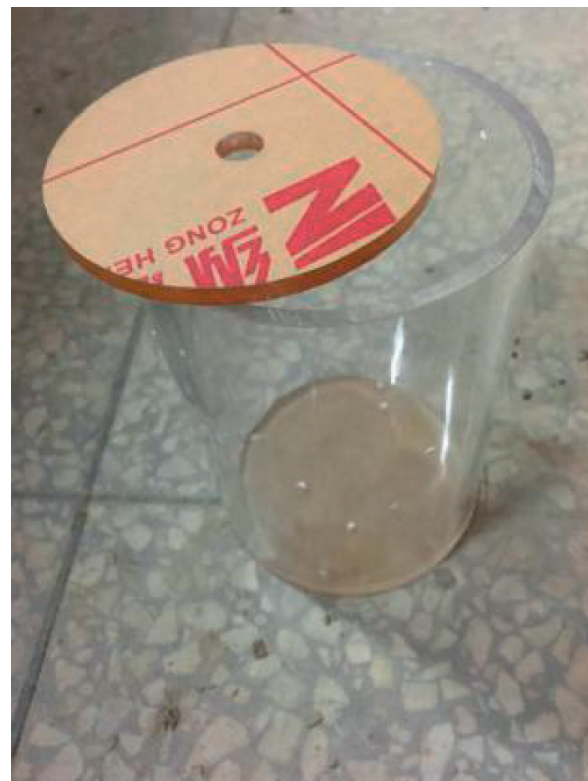

(a)

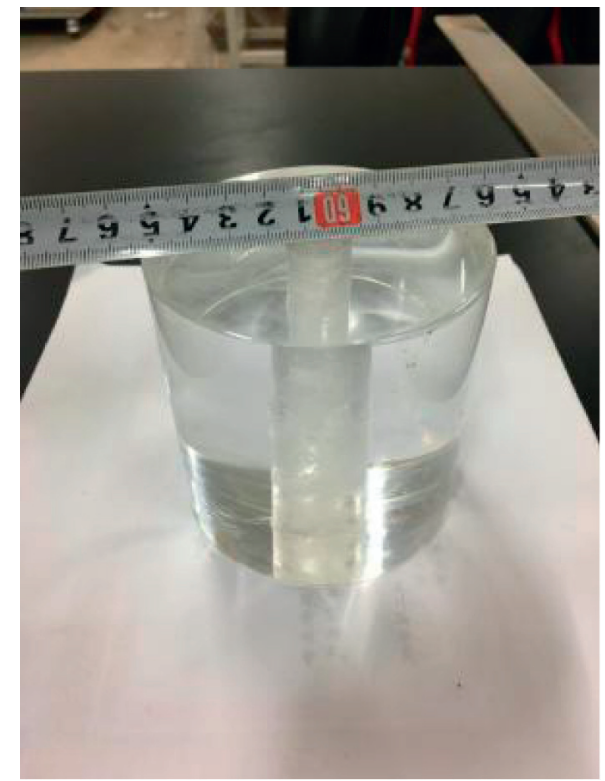

(b)

Figure 3: Plexiglass cylinder (a) and plexiglass hollow transfer column (b).

The pressure plate was made of plexiglass with a thickness of $5 \mathrm{~mm}$, an outside diameter of $98 \mathrm{~mm}$, and a central circular hole with an inner diameter of $13 \mathrm{~mm}$. The purpose of the central circular hole is to provide an upward displacement space for the timber rod (or drained-timber rod) in the process of loading and consolidation, as shown in Figure 3(a). 
The Plexiglass hollow transfer column was made of plexiglass with a height of $90 \mathrm{~mm}$, an outside diameter of $90 \mathrm{~mm}$, and a central hole with an inner diameter of $16 \mathrm{~mm}$, as shown in Figure 3(b).

2.5. Design of Eight Types of Soil-Column Consolidation Tests. In order to verify the drainage consolidation performance of the drained-timber rod, a total of eight types of soil-column consolidation tests were designed, as listed in Table 2. In all the tests, the initial height of the soil column was set to $100 \mathrm{~mm}$, the total length of the (drained) timber rod was $150 \mathrm{~mm}$, and the embedded length in the soil of the rod was $100 \mathrm{~mm}$. From the viewpoint of the purpose of the experiment, the eight types of tests can be divided into three groups, Group A (L1, L2, L3, S0), Group B (M1, S0, M2), and Group C (N1, S0, N2).

Group A (L1, L2, L3, S0) was designed to investigate the effect of drainage condition, in which test L1 is just soil column at a vertical upward drainage condition; test L2 is soil column with just timber rod at vertical upward drainage condition; test L3 is a soil column with a drained-timber rod at radial drainage condition, and the top boundary of the soil column was sealed with a thin geomembrane; test S0 is soil column with a drained-timber rod at both vertical upward drainage and a radial drainage condition, designed as the basic standard tests for the drained-timber rod.

Group B (M1, S0, M2) was designed to investigate the influence of the diameter of the timber rod, in which the thickness of the drained geotextile is of two layers (the drained geotextile has two layers) and the drainage condition is the same (vertical + radial); the only difference is that the diameters of the timber rods are $8 \mathrm{~mm}, 10 \mathrm{~mm}$, and $12 \mathrm{~mm}$ for tests $\mathrm{M} 1, \mathrm{~S} 0$, and $\mathrm{M} 2$, respectively.

Group C (N1, S0, N2) was designed to investigate the influence of the layers of the drained geotextile, in which the diameter of the timber rod is $10 \mathrm{~mm}$ and the drainage condition is the same (vertical + radial); the only difference is the number of the drained layers of the geotextiles, which is 1,2 , and 4 for tests $\mathrm{N} 1, \mathrm{~S} 0$, and N2, respectively.

\section{Test Procedures}

3.1. Preparation of the Soil-Column Samples. The soil-column samples were prepared in the following steps: (1) the soil was placed with an initial moisture content of $90.06 \%$ into the plexiglass cylinder with a $100 \mathrm{~mm}$ in height; (2) a timber rod was inserted (or a drained-timber rod) vertically into the soil column at the central position and up to the bottom of the cylinder, which means the embedded length of the (drained) timber rod is $100 \mathrm{~mm}$; (3) a piece of permeable geotextile pad was placed on the top surface of the soil column, the geotextile pad has a diameter of $100 \mathrm{~mm}$, a thickness of $3 \mathrm{~mm}$, and a center hole with a diameter of $13 \mathrm{~mm}$; (4) the pressure plate was placed on the top of the drained pad; and (5) the hollow transfer column was placed on the pressure plate (note: for test L3, a piece of impermeable geomembrane pad was used to take the place of the permeable geotextile to achieve the only radial drainage condition). The photo of the soil-column consolidation sample before loading is shown in Figure 4.

3.2. Step Loading Scheme. The apparatus of loading and monitoring system is shown in Figure 5. The loading scheme is designed in 6 steps, which are $6.25 \mathrm{kPa}, 12.50 \mathrm{kPa}, 25 \mathrm{kPa}$, $50 \mathrm{kPa}, 100 \mathrm{kPa}$, and $200 \mathrm{kPa}$, respectively; each loading step is maintained for 24 hours, and the consolidation settlement with time is monitored and recorded for analysis.

3.3. Undrained Shear Strength Tests. After loading and consolidation, the (drained) timber rod was removed carefully, the inner hole left by the rod was filled using the consolidated clay with the same water content; then, a special sampler was employed to shape a sample with a diameter of $50 \mathrm{~mm}$ and a height of $100 \mathrm{~mm}$; and finally, the unconfined compression strength test was performed, the undrained shear strength $C_{\mathrm{u}}$ was derived, and the water content of the sample was measured.

\section{Analysis and Discussion of the Test Results}

4.1. Evaluation of Radial Drainage of Drained-Timber Rods (Group A: L1, L2, L3, S0). For the tests of Group A (L1, L2, L3, S0), the relationship between the consolidation settlement and the time in each step of loading is plotted in Figure 6 and the relationship between the final void ratio and consolidation pressure is plotted in Figure 7.

Figure 6 indicates that (1) for test L1 and test L2, the settlement curves with time under each loading step are almost similar, meaning that the traditional timber rod is impermeable and has little contribution to increasing the consolidation degree of soft clay, which is reasonable and agrees with the theoretical speculation; (2) comparing the curves of test L2 and test S0, the only difference is that a drained-timber rod is used in test $\mathrm{S} 0$ and a timber rod is used in L2. It reveals that, under the same loading and drained condition, the two geotextile layers of the drained-timber rod can play the role of radial drainage well and contribute a lot to the total consolidation degree; (3) for the test L3 and test S0, the settlement curves under each loading step are almost similar, it means that for the drained-timber rods, with two drained layers of geotextile, the radial drainage has a dominant contribution to the total consolidation degree, and the vertical drainage has little contribution to the total consolidation degree, the phenomenon reveals that the two thin layers of geotextile are quite effective for increasing the radial consolidation.

Figure 7 indicates that, under the same load increment and the same consolidation time ( 24 hours), the increments of consolidation settlement of tests L3 and S0 are always greater than those of the tests L1 and L2, which reveals that the drainage layer structure of the drained-timber rods can effectively improve the consolidation degree of the soft clay. the Consolidation Settlement (Group B: M1, S0, M2). For the 
Table 2: Set up of soil-column consolidation tests with (drained) timber rods.

\begin{tabular}{|c|c|c|c|c|c|c|c|}
\hline $\begin{array}{l}\text { Purpose of soil-column } \\
\text { tests }\end{array}$ & $\begin{array}{l}\text { Type of } \\
\text { tests }\end{array}$ & $\begin{array}{l}\text { Pile diameter } \\
(\mathrm{mm})\end{array}$ & $\begin{array}{c}\text { Geotextile } \\
\text { layers }\end{array}$ & $\begin{array}{c}\text { Outside pile } \\
\text { diameter }(\mathrm{mm})\end{array}$ & $\begin{array}{c}\text { Length of embedded } \\
\text { pile }(\mathrm{mm})\end{array}$ & $\begin{array}{l}\text { Vertical } \\
\text { drain }\end{array}$ & $\begin{array}{c}\text { Radial } \\
\text { drain }\end{array}$ \\
\hline \multirow{4}{*}{$\begin{array}{l}\text { Effect of drainage } \\
\text { condition (Group A) }\end{array}$} & L1 & No & No & No & No & $\checkmark$ & - \\
\hline & $\mathrm{L} 2$ & 10 & No & 10 & 100 & $\checkmark$ & - \\
\hline & L3 & 10 & 2 layers & 14 & 100 & - & $\checkmark$ \\
\hline & So & 10 & 2 layers & 14 & 100 & $\checkmark$ & $\checkmark$ \\
\hline \multirow{3}{*}{$\begin{array}{l}\text { Effect of pile diameter } \\
\text { (Group B) }\end{array}$} & M1 & 8 & 2 layers & 12 & 100 & $\checkmark$ & $\checkmark$ \\
\hline & So & 10 & 2 layers & 14 & 100 & $\checkmark$ & $\checkmark$ \\
\hline & M2 & 12 & 2 layers & 16 & 100 & $\checkmark$ & $\checkmark$ \\
\hline \multirow{3}{*}{ Effect of layers (Group C) } & N1 & 10 & 1 layer & 12 & 100 & $\checkmark$ & $\checkmark$ \\
\hline & So & 10 & 2 layers & 14 & 100 & $\checkmark$ & $\checkmark$ \\
\hline & $\mathrm{N} 2$ & 10 & 4 layers & 18 & 100 & $\checkmark$ & $\checkmark$ \\
\hline
\end{tabular}

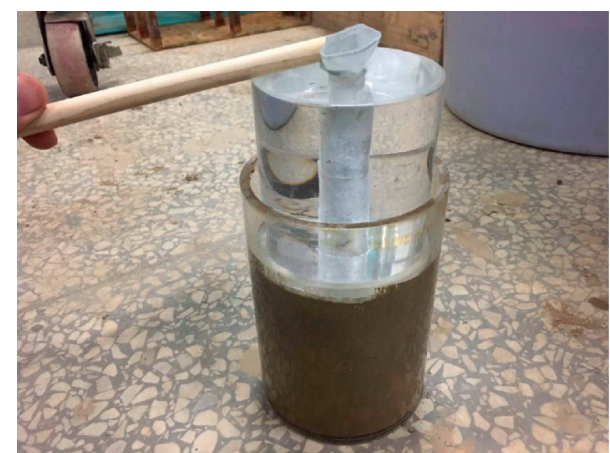

FIgURE 4: Set up of soil column with (drained) timber bolt before loading.

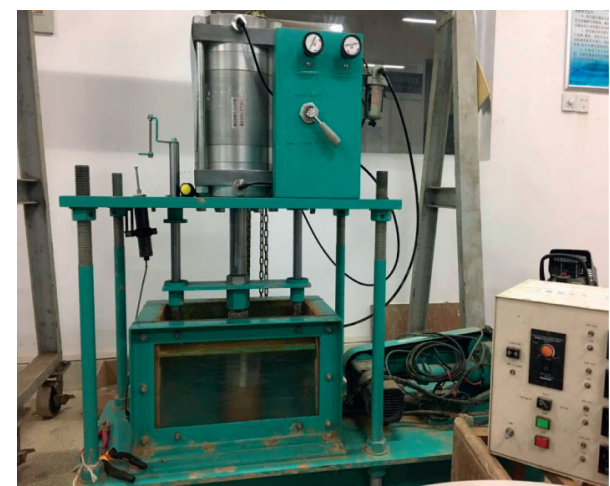

Figure 5: Apparatus of loading and monitoring system.

tests of Group B (M1, S0, M2), the relationship between the consolidation settlement and the time in each loading step is plotted in Figure 8 and the relationship between the final void ratio and the consolidation pressure is plotted in Figure 9.

Figures 8 and 9 indicate that the rod diameter has an obvious influence on the consolidation settlement. It seems that, under the same loading and consolidation conditions, the settlement increases with the increase of the rod diameter in each loading step. The reason may be the outside diameter of the drained-timber rod even if the three tests (M1, S0, M2) have the same two layers of drained geotextiles, which will be further confirmed in the later discussion.

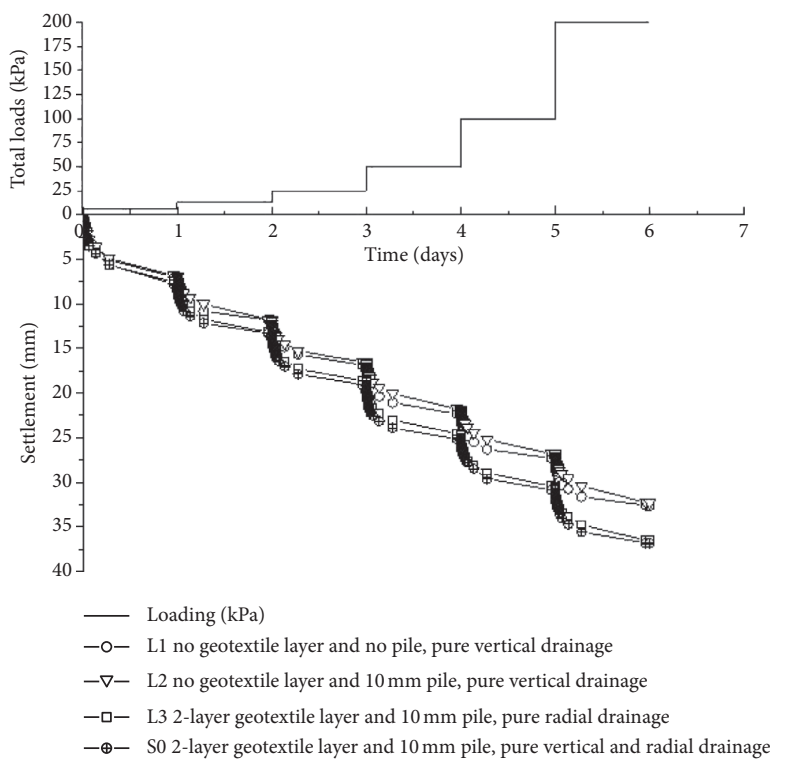

Figure 6: Relationships between consolidation settlement and time under each step loading for tests of Group A (L1, L2, L3, S0).

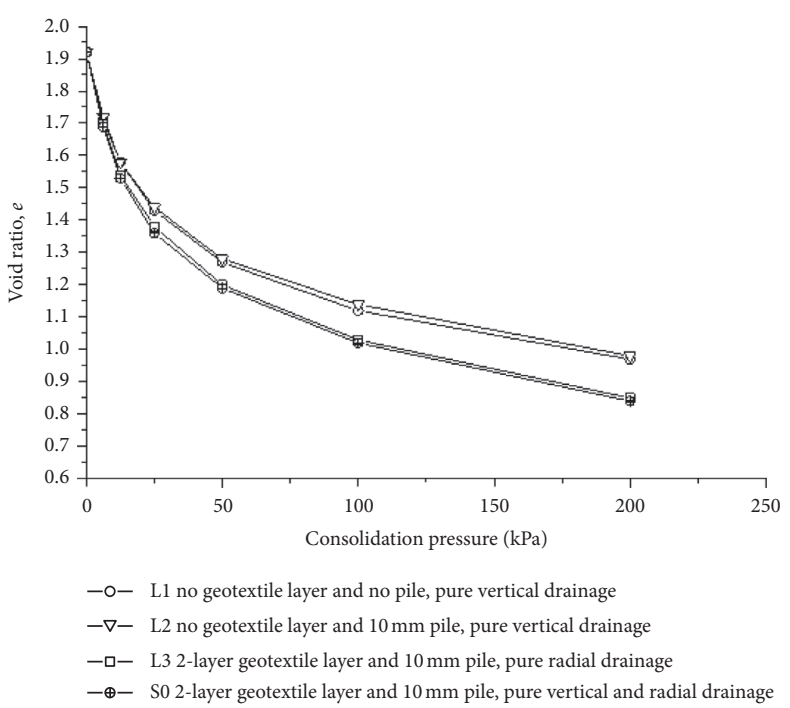

FIgURE 7: Curves of void ratio versus consolidation pressure for tests of Group A (L1, L2, L3, S0). 


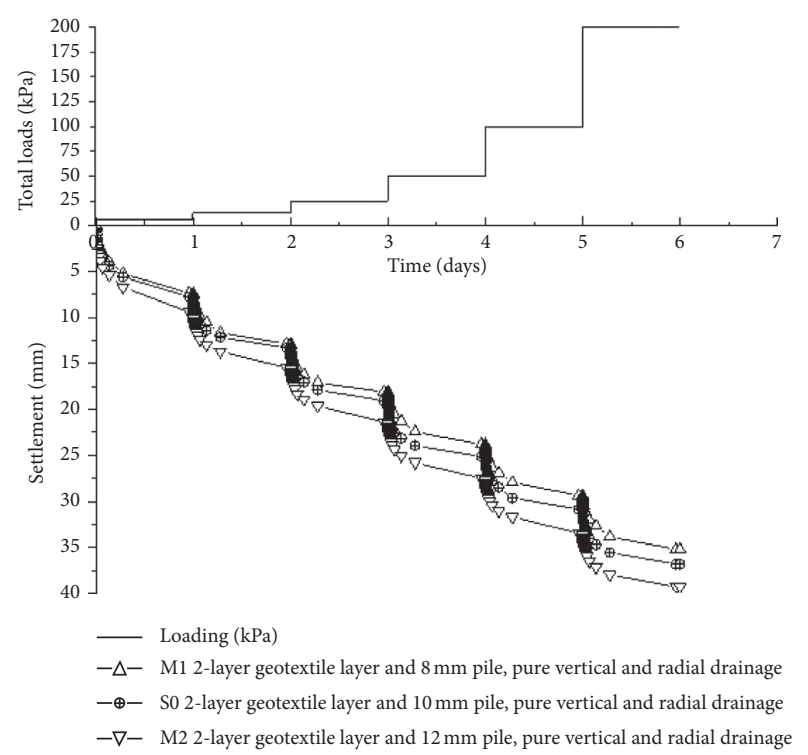

FIGURE 8: Relationships between consolidation settlement and time under each step loading for tests of Group B (M1, S0, M2).

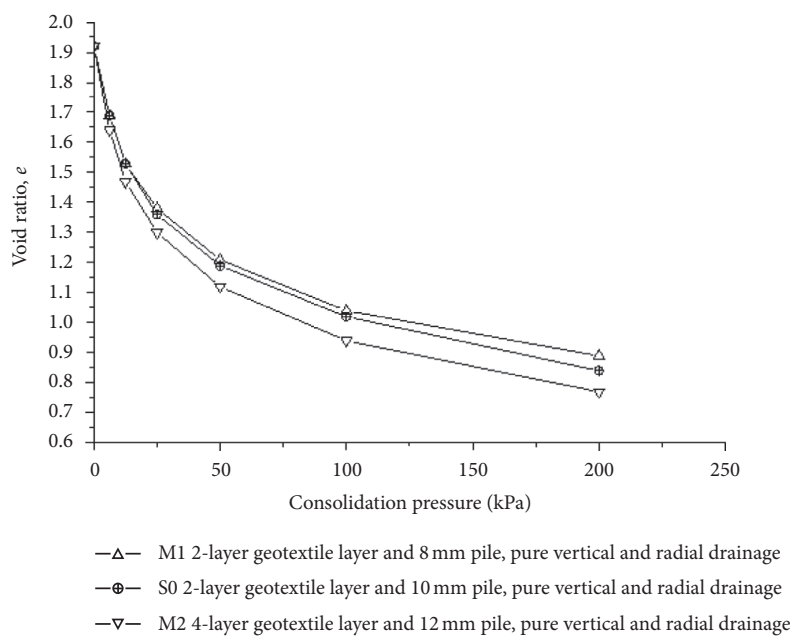

FIgURE 9: Curves of void ratio versus consolidation pressure for tests of Group B (M1, S0, M2).

4.3. Influence of the Thickness of Drained Layers on the Consolidation Settlement (Group C: N1, SO, N2). For the tests of Group C (N1, S0, N2), the relationship between the consolidation settlement and the time in each step of loading is plotted in Figure 10 and the relationship between the final void ratio and the consolidation pressure is plotted in Figure 11.

Figures 10 and 11 indicate that the layers of drained geotextile have an obvious influence on the consolidation settlement. It seems that, under the same loading and consolidation condition, the settlement increases with the increasing of the thickness of layers in each step of loading. The reason may be the outside diameter of the drainedtimber rod, which increased with the increase of the layers of drained geotextiles, even if the three tests $(\mathrm{N} 1, \mathrm{~S} 0, \mathrm{~N} 2)$ have

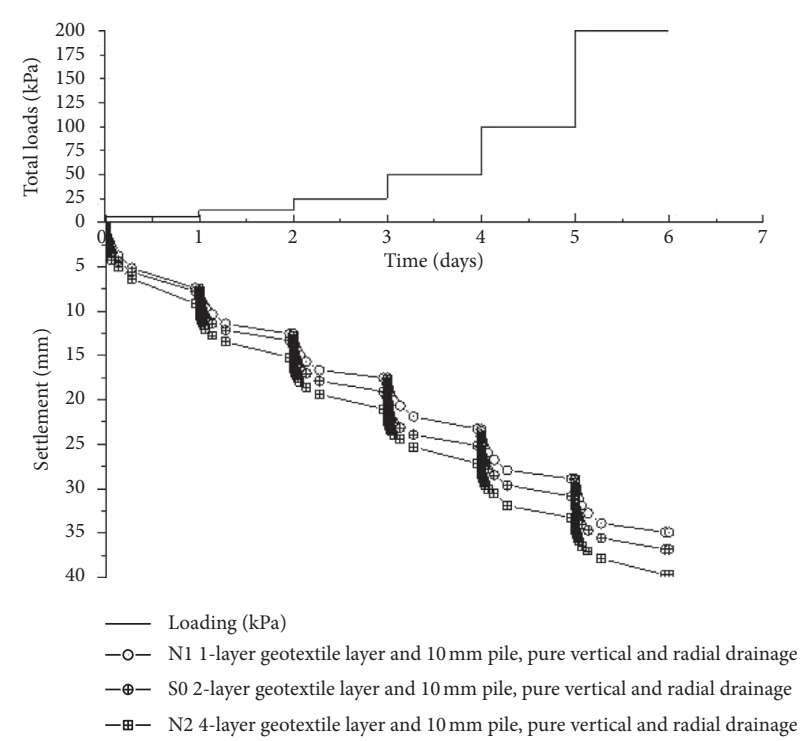

Figure 10: Relationships between consolidation settlement and time under each step loading for tests of Group C (N1, S0, N2).

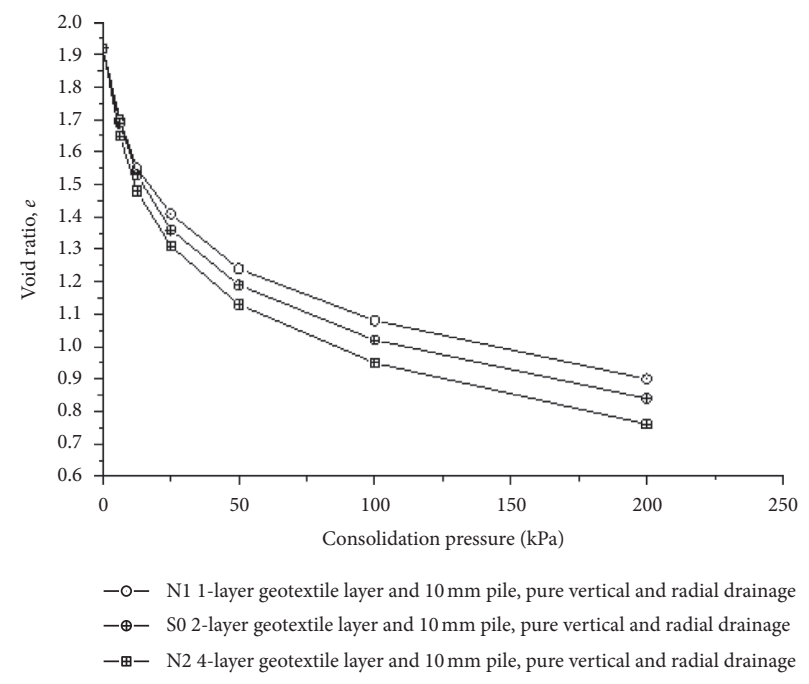

FIGURE 11: Curves of void ratio versus consolidation pressure for tests of Group C (N1, S0, N2).

the same diameter of timber rod; this will be further confirmed in later discussion.

4.4. The Relationship of the Undrained Shear Strength versus the Liquidity Index of the Consolidated Soft Clay. The final consolidation settlements of the eight types of tests are listed in Table 3. After loading and consolidation of each type of test, the unconfined compression strength test was performed and the corresponding undrained shear strength $\left(C_{\mathrm{u}}\right)$ was derived; also the water content corresponding to the final state was measured, and the corresponding liquidity index was measured by liquid-plastic combine tester as listed in Table 3. 
TABLE 3: Summary of soil-column consolidation test results.

\begin{tabular}{lcccccc}
\hline Purpose of test & Type of tests & Final settlement $(\mathrm{mm})$ & Final void ratio & $\begin{array}{c}\text { Water } \\
\text { content (\%) }\end{array}$ & $\begin{array}{c}\text { Liquidity index } \\
\text { strength (kPa) }\end{array}$ \\
\hline \multirow{4}{*}{ Effect of drainage condition } & L1 & 32.60 & 0.97 & 50.25 & 0.93 & 13.02 \\
& L2 & 32.27 & 0.98 & 50.74 & 0.94 & 13.19 \\
& L3 & 36.52 & 0.85 & 46.21 & 0.77 & 17.49 \\
& S0 & 36.85 & 0.84 & 46.05 & 0.77 & 17.61 \\
\hline \multirow{3}{*}{ Effect of pile diameter } & M1 & 35.24 & 0.89 & 47.19 & 0.81 & 15.90 \\
& S0 & 36.85 & 0.84 & 46.05 & 0.77 & 17.61 \\
& M2 & 39.31 & 0.77 & 42.57 & 0.63 & 20.76 \\
Effect of geotextile layers & N1 & 34.91 & 0.90 & 47.84 & 0.83 & 15.34 \\
& S0 & 36.85 & 0.84 & 46.05 & 0.77 & 0.64 \\
\hline
\end{tabular}

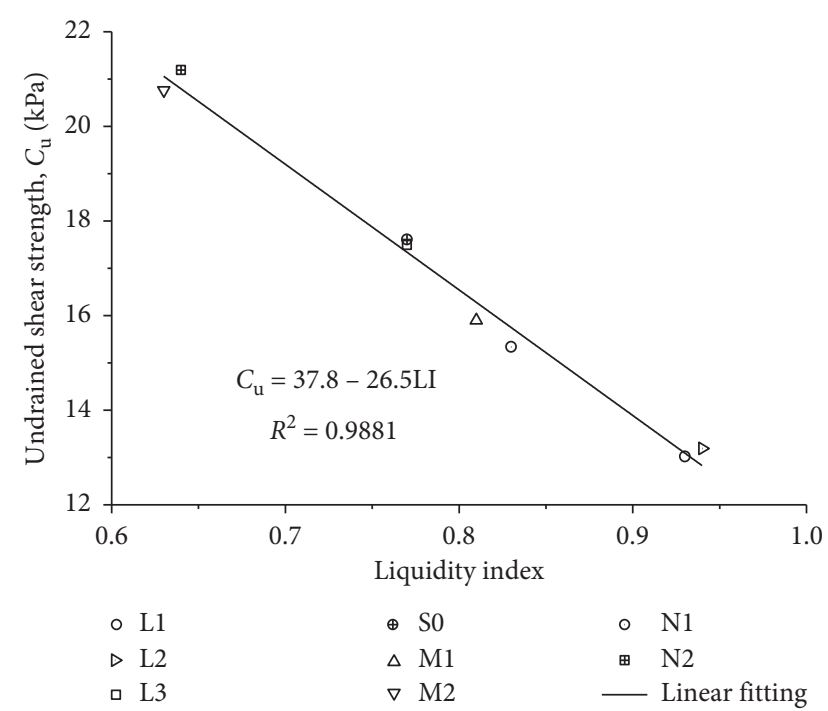

FIgURE 12: Relationship of undrained shear strength versus liquidity index of the consolidated soft clay.

For each certain soft clay at the plastic state condition, there is a certain relationship between the undrained shear strength and the water content (or liquidity index); therefore, the undrained shear strength is another parameter which can be used indirectly to evaluate the consolidation effect of the soft clay. For the eight types of tests, the relationship between the undrained shear strength and the liquidity index corresponding to the final state is plotted in Figure 12.

Figure 12 indicates that (1) there is quite a good linear relationship between the undrained shear strength and the water content for the final state of the eight types of consolidation tests, which means that the data of eight types of soil-column tests is good and reasonable; (2) the data points in test L1 and test L2 are quite close and result in the lowest undrained shear strength about $13.1 \mathrm{kPa}$, which means the traditional timber rod has little contribution to the total consolidation degree; (3) the data points of test L3 and test S0 are very close and give the undrained shear strength about $17.6 \mathrm{kPa}$, which means in the tests with drained-timber rods, and the radial drainage plays a leading role in the total consolidation degree, which means that the drained-timber rod is effective; (4) the data points of test M2 and test N2 are quite close and give the highest undrained shear strength, about $21.1 \mathrm{kPa}$, with the outside diameters of the drainedtimber rods equal to $16 \mathrm{~mm}$ and $18 \mathrm{~mm}$ for test $\mathrm{M} 2$ and test $\mathrm{N} 2$, respectively, the data points of test $\mathrm{M} 1$ and test $\mathrm{N} 1$ are relatively close, the corresponding undrained shear strength is $15.9 \mathrm{kPa}$ and $15.3 \mathrm{kPa}$ respectively, and the outside diameters for both $\mathrm{M} 1$ and $\mathrm{N} 1$ are about $12 \mathrm{~mm}$; and (5) the comparison of the three sets of data points from M1-N1, L3S0, and M2-N2 reveals that the outside diameter of the drained-timber rod has a significant influence on the consolidation effect: the larger the outside diameter of the drained-timber rod, the higher the undrained shear strength; for the same outside diameters of the drained-timber rod, the thicker the drained layer, the higher the undrained shear strength.

\section{Conclusions}

Aiming to improve the weakness of the traditional timber pile in reinforcing soft clay foundations, the drained-timber pile technique was presented. To verify the effectiveness and feasibility of the drained-timber piles, a special laboratory soil-column consolidation apparatus was designed and eight types of soil-column consolidation tests with drained-timber rods were carried out. The conclusions are the following:

(1) The thin layer of geotextile for the drained-timber rod can play well the role of radial consolidation when compared with traditional timber rod; the drained-timber rod can obviously increase the consolidation settlement due to the drained layer structure of the drained-timber rod.

(2) For the soil-column consolidation tests with drained-timber rods, the radial drainage has a dominant contribution to the total consolidation degree, and the vertical drainage has little contribution to the total consolidation degree.

(3) The outside diameter of the drained-timber rod has significance influence on the consolidation settlement; the larger the outside diameter of the drainedtimber rod, the higher the undrained shear strength; for the same outer diameters of the drained-timber 
rods, the thicker the drained layer, the higher the undrained shear strength.

(4) It is recommended that the effectiveness and contribution of the drained-timber pile should be evaluated further in a longer soil-column model test.

(5) It can be expected that the drained-timber pile technique will have a useful application for the construction of the medium and small hydraulic structures, and also the drained-timber pile technique will have a certain application for the treatment of a large area of soft foundation.

\section{Data Availability}

The data used to support the findings of this study are included within the article.

\section{Conflicts of Interest}

The authors declare that they have no conflicts of interest.

\section{Acknowledgments}

This work was supported by the National Natural Science Foundation of China (Grants nos. 51668002, 51368002, and 50968001), the Natural Science Foundation (20151BAB206056 and 20151BAB206053) of Jiangxi Provincial Department of Science and Technology, the Science and Technology Support Program (20151BBE50014) of Jiangxi Provincial Department of Science and Technology, and the Science and Technology Project of Jiangxi Provincial Department of Education (GJJ150580).

\section{References}

[1] S. Hayashi and Y.-J. Du, "Geotechnical analysis of Mizuki embankment remains," Soils and Foundations, vol. 45, no. 6, pp. 43-53, 2005.

[2] Nanjing Museum and Taizhou Museum, "Excavation report of the ancient water gate site in southern Taizhou, Jiangsu Province," Southeast Culture, vol. 15, no. 1, pp. 43-52, 2014, in Chinese.

[3] J.-C. Chai, S. Shrestha, T. Hino, W.-Q. Ding, Y. Kamo, and J. Carter, "2D and 3D analyses of an embankment on clay improved by soil-cement columns," Computers and Geotechnics, vol. 68, pp. 28-37, 2015.

[4] T. Hino, J.-C. Chai, T. Negami, D. T. Bergado, and R. Jia, "Assessment of the effects of sea-level change on the geoenvironment: the case of Teh Ariake sea coastal lowlands," in Proceedings of the 9th International Symposium on Lowland Technology (ISLT 2014), pp. 21-30, Saga, Japan, 2014.

[5] B. Indraratna, C. Rujikiatkamjorn, J. Ameratunga, and P. Boyle, "Performance and prediction of vacuum combined surcharge consolidation at Port of Brisbane," Journal of Geotechnical and Geoenvironmental Engineering, vol. 137, no. 11, pp. 1009-1018, 2011.

[6] N. Z. Xi and H. C. Yu, "Dialectical thinking on treatment technology for large-area soft foundation," Chinese Journal of Geotechnical Engineering, vol. 35, no. 2, pp. 584-587, 2013.
[7] J. H. Ao and H. G. Zhai, "Application of timber piles in reinforcing the foundation of retaining wall," City Road and Flood Control, vol. 70, no. 7, pp. 231-235, 2009, in Chinese.

[8] W. P. Chen, "Design and construction of timber piles in soft clay ground," Journal of Guangdong Technical College of Water Resources and Electric Engineering, vol. 3, no. 1, pp. 49-53, 2005, in Chinese.

[9] S. B. Yu, "Application of deal pile foundation in Xishalianwei tide gate," Guangxi Water Resources and Hydropower Engineering, vol. 2005, no. 2, pp. 25-27, 2005, in Chinese.

[10] T. Yang, J. Zhou, and C. Zhou, "Analysis and design of timberpile composite foundation on soft soils," Chinese Journal of Roch Mechanics and Engineerings, vol. 22, no. 9, pp. 15601565, 2003, in Chinese.

[11] P. Poungchompu, S. Hayashi, D. Suetsugu, and Y. J. Du, "Investigation into performance of raft \& pile supported embankment on soft ground," Geotechnical Engineering Journal, vol. 39, no. 4, pp. 185-190, 2008.

[12] P. Poungchompu, S. Hayashi, D. Suetsugu, Y. J. Du, and M. C. Alfro, "Performance of raft \& pile foundation on soft Ariake clay ground under embankment loading," Lowland Technology International, vol. 12, no. 1, pp. 41-46, 2010.

[13] X. J. Chai, C. F. He, X. J. Li, and Q. R. Lu, "Laboratory model tests on drainage consolidation performance of drainedtimber pile," in Proceedings of the 2017 3rd International Conference on Civil, Hydraulic and Environmental Engineering (ICCHEE 2017), Shenzhen, ChinaIn press, Shenzhen, China, November 2017.

[14] Y. F. Xiong, "The indoor columnar model experiment on the flexibility drainage pine poles reinforcement soft soil foundation," Master thesis, East China University of Technology, Fuzhou, China, 2017. 